\title{
USING METAPHORS TO REDUCE ANXIETY IN ADOLESCENTS
}

\author{
Elena Carmen Bolovan ${ }^{1}$, Ileana-Loredana Vitalia ${ }^{2^{*}}$ \\ ${ }^{1}$ University of Pitesti, Master of Clinical Psychology: evaluation and intervention, Pitesti, Romania \\ ${ }^{2}$ Ph.D. Associate Professor, University of Pitești, Department of Psychology, \\ Communication Sciences and Social Assistance, Pitesti, Romania
}

\section{Current Trends in}

\section{Natural Sciences}

\begin{abstract}
The age of adolescence represents few years of uncertainties and unknown in the development and evolution of a young people. In the search of his own identity, the adolescent needs symbols in order to access the unconscious personal resources. Working with metaphors in the process of counselling and psychotherapy facilitates new signification and sense for the adolescent that experience the most provocative period of his life. This article focuses on the benefits of using metaphorical techniques to improve emotional health in adolescents. We supposed that using a brief experiential metaphoric exercise (My own relaxation and recreation place) would allow the group members to improve their present emotional anxiety experience. The adolescents became more aware of their inner resources (such as tranquillity, calm, trust and hope) and needs.

Present finding indicate the effects of expressive-creative methods on anxiety state. Using metaphor in the therapy of adolescents could be an important method to reduce the anxiety and to help them understand the role of their emotions in the process of personal development.
\end{abstract}

Keywords: Expressive-creative methods, emotional health, personal development

\section{INTRODUCTION}

The issue of anxiety may be considered as a nodal point referred to the most difeerent and most important question, an enigma whose resolution should lighten up our whole inner psychological life (Freud, 2004, p.434). The anxiety represents an emotion characterized by intranquillity, concern, tension, fear felt by the adolescent like an imminent danger referred of his confusing future. A little of anxiety could help the motivation of learning, of developing the personal potential and it could be used to keep people out of risks. But, the persistent anxiety could interfere with adolescent's scholar activities, with the family and friends relationship and even with the joy of life. The anxiety stops the adolescent to become autonomous and accomplished and block his tendency of actualization. The anxiety represents a way of emotional self-regulation. The experiential psychotherapy is focused on now and here moment and try to assist the adolescent to express his own emotions using metaphoric techniques which helps the young teenager exploring, discovering and defining himself by reaching his possibilities, his spontaneity, his creativity and the manifestation of his personal potential (Răban - Motounu, 2020; Vitalia, 2019, 2017). 
The metaphor represents a dynamic and developing way to acces the personal psychological resources acting like a fast and surprising connection between unconscious and conscious mind (Mitrofan, 2000, p.291). The therapeutic metaphor has an instant acces to the personal experiences and needs.

Many studies show that using metaphor as therapeutic instrument may be efficient in the approach of anxiety. The metaphor deactivates the personal defense mechanisms without increase the anxiety. The adolescent could take a step back from his existential difficulty and he could focus on the metaphoric exercise for refocus on his problem with new informations and action possibilities won in metaphoric interaction (Witztum, Hart, Friedman, 1988).

The present study focussed on the benefits of using metaphor techniques on anxiety experience. Hypothesis: We supposed that the anxiety state and the anxiety trait would decrease after a metaphoric exercise.

\section{MATERIALS AND METHODS}

Method: The present study is based on an experimental design. The dependent variables were the anxiety state and anxiety trait. The independent variable was the participation on the metaphoric exercise based on Metaphor of your own relaxation and recreation place, created for this particularly study.

Psychometrical methods: State - Trait Anxiety Inventory C (STAI-C) Form and Statistical methods.

Instruments: STAI is a commonly used measure of trait and state anxiety. The instrument distinguishes between how prone a child is to anxious behaviour and emotional anxiety. It includes two sets of 40 questions, 20 questions for $\mathrm{A}$ - State anxiety and 20 questions for $\mathrm{A}$ - Trait anxiety that can be verbally read to younger children. Internal consistency coefficients for the scale have ranged from .86 to .95 ; test - retest reliability coefficients have ranged from .65 to .75 over a two months interval.

Participants: 20 adolescents students in $7^{\text {th }}$ grade participated in this experiment, 12 of them were female and eight were male. On average, participants were 13 years old.

Procedure: We used a metaphoric exercise based on Metaphor of your own relaxation and recreation place, created particularly for this study and presented as a guided imagery meditation. The experiment took place on - line, via Skype.

The participants were asked to sit in a relaxing position, noticing how they feel. The researcher asked them to follow a road and finding a right and calm place of their own good for relaxation and recreation. The participants were guided to feel and pay attention on their sensatios, emotions and thoughts. They were encouraged to continue focus on their experience, to create their own place of relaxation and recreation, to bring their awareness to their feelings and emotions, to notice every sensation of their bodies and to try customize their own place of relaxation and recreation.

Each participant from the experimental group completed ratings about the current anxiety state and trait before and after the metaphoric exercise.

\section{RESULTS AND DISCUSSIONS}

Statistical analysis was performed to test the hypothesis of this study. Paired Samples T Test was used to identify the differences of STAI-C scores before and after the Metaphor of your own relaxation and recreation place exercise. Statistical results revealed significant differences for 
anxiety state $(\mathrm{t}=4.323$; $\mathrm{sig}=0.002)$ and anxiety trait $(\mathrm{t}=5.014$; $\mathrm{sig}=0.001)$. The hypothesis assuming a positive immediate effect of metaphoric exercise on anxiety was confirmed by the data. We also compared the scores of experimental group by the scores of control group. The Independent $\mathrm{T}$ Test revealed a significant differences between the two groups.

Table 1: Group Statistics - t test results

\begin{tabular}{|l|c|c|c|}
\hline & $\mathrm{t}$ & Sig/2 tailed & $\mathrm{p}$ \\
\hline State Anxiety & -4.138 & 0.001 & 0.05 \\
\hline Trait Anxiety & -2.483 & 0.023 & 0.05 \\
\hline
\end{tabular}

The data confirmed the hypothesis of the study that the metaphoric exercise decreased the level of anxiety.

\section{Discussion}

The metaphoric exercise decreased the level of anxiety state and anxiety trait. This exercise was based on the power of metaphor, considered an expressive-creative technique, used in the approach of anxiety in adolescence age. The purpose of using the „Metaphor of your own relaxation and recreation place" is the spontaneously personal exploring and discovering of the own psychological resources that could creatively help the adolescent to develop his personality.

Using metaphor in the approach of adolescent anxiety reveal the psychological resources of the young and it could activate new information of himself that could recreate new strategies for extending the capacities of transforming his personal experiences (Vitalia, 2020).

The creative images used in the metaphoric exercise have helped the adolescents to relax, to express themselves, and to be open and confident about experiencing their own reality.

The participants were asked to focus on their sensations an emotions and this experience was calming and allowed them to deep below the concerns of their minds into relaxation and security, to be creative, spontaneous, to focus on their own symbols and new signification accomplished while experimenting the metaphor of their own place of relaxation and recreation.

\section{CONCLUSIONS}

Present finding indicates the effects of expressive-creative metaphor on anxiety state. This experience was associated with decreased levels of anxiety (participants felt more calm, fearless, confident and less worried). Using metaphor in the psychotherapy on adolescents could be an important method to treat their anxiety and to help them to understand the role of their emotions in the evolution of human personality.

\section{REFERENCES}

Freud, Sigmund (2004). Opere, vol. 10, Introducere în psihanaliză [Introduction to psychoanalysis], București, Ed. Trei. Mitrofan, Iolanda (2000). Orientarea experiențială în psihoterapie [Experiential approach in psychotherapy], București, Ed. SPER.

Răban-Motounu, N. (2020). Empathic Care: New Perspectives. Current Trends in Natural Sciences, 9(18), $189-193$. https://doi.org/10.47068/ctns.2020.v9i18.025

Răban-Motounu, N., Vitalia, I.L (2010). Personal optimization groups centered on unification psychotherapy with adolescents, International Conference EDU-WORLD, Oct., Piteşti, Romania, Procedia EDU-WORLD, p.548555, ISSN 1844-6272

Răban-Motounu, N., Vitalia, I.L. (2014). Awareness Techniques and Emotional Change. Journal of Experiential Psychotherapy 17(3),67, 3-11 


\section{Current Trends in Natural Sciences}

Vol. 10, Issue 20, pp. 203-206, 2021

https://doi.org/10.47068/ctns.2021.v10i20.027

Current Trends in Natural Sciences (on-line)

ISSN: 2284-953X

Current Trends in Natural Sciences (CD-Rom)

ISSN-L: 2284-9521

ISSN: 2284-9521

ISSN-L: 2284-9521

Vitalia, I.L. (2017). Exploring the potential benefits of nature based experience on anxiety. Current Trends in Natural Sciences, 6(12), 152-155.

Vitalia, I.L. (2019). The Breath - The Experience Of Being Present. Current Trends in Natural Sciences, 8(16), 196199.

Witztum, Eliezer; Van Der Hart, Onno; Friedman, Barbara (1988). The Use of Metaphors in Psychotherapy, Journal of Contemporary Psychotherapy, 18 (4), 270-290. 